\title{
Gross alpha and beta activities in surface, underground and drinking waters of a high natural radioactivity region of central south Bahia state, Brazil
}

\author{
L. Sousa Silva ${ }^{1,2}$ and B.R.S. Pecequilo ${ }^{1}$ \\ ${ }^{1}$ Environmental Radiometric Division, Instituto de Pesquisas Energéticas e Nucleares, Av. \\ Prof. Lineu Prestes, 2242, Cidade Universitária, 05508-000, São Paulo, SP, Brazil \\ e-mail: brigitte@ipen.br \\ ${ }^{2}$ State University of Bahia, UNEB, Campus Caetité, BA, Brazil
}

\begin{abstract}
The levels of gross alpha and beta natural radioactivities in surface, underground and drinking waters consumed by the urban and rural population living in Lagoa Real Uranium Province of central south Bahia state, Brazil were determined in several samples collected from urban public supply of drinking water and, in the rural area, from dug and drilled wells and also from small dams and reservoirs supplied with rainfall. After pre-concentration, the samples were evaporated under an infrared lamp on an inox planchet and subsequently counted on a thin end-window low-background proportional counter, namely Berthold LB 770. Preliminary results show natural radiation levels varying from $0.02 \pm 0.001 \mathrm{~Bq} / \mathrm{L}$ to $0.80 \pm 0.04$ $\mathrm{Bq} / \mathrm{L}$ for gross alpha activity and from $0.010 \pm 0.006$ to $3.0 \pm 0.2 \mathrm{~Bq} / \mathrm{L}$ for gross beta activity. Some values exceed the 2004 WHO recommendation levels that the screening levels for drinking water below which no further action is required are $0,5 \mathrm{~Bq} /$ litre for gross alpha activity and $1 \mathrm{~Bq} /$ litre for gross beta activity. However, as we are dealing with natural radiation in a well-known high background radiation area, more studies are needed.
\end{abstract}

\section{INTRODUCTION}

Natural radioisotopes as ${ }^{40} \mathrm{~K}$ and the nuclides from the ${ }^{238} \mathrm{U}$ and ${ }^{232} \mathrm{Th}$ series are the greatest source of internal and external exposure in human beings. External radiation is originated from cosmic rays and terrestrial radiation, while the ingestion and inhalation of natural radionuclides lead to the dosis for internal radiation. Among the radionuclides of terrestrial origin, ${ }^{40} \mathrm{~K}$ and the constituents of the ${ }^{238} \mathrm{U}$ and ${ }^{232} \mathrm{Th}$ series enter the human body largely by food and water ingestion [1], being the total exposure per person resulting of the ingestion of radioisotopes of terrestrial origin $0,29 \mathrm{mSv}$, from which $0,17 \mathrm{mSv}$ due to the ${ }^{40} \mathrm{~K}$ and $0,12 \mathrm{mSv}$ due to the radionuclides of the ${ }^{238} \mathrm{U}$ e ${ }^{232} \mathrm{Th}$ series. The ${ }^{238} \mathrm{U}$ represents $99,28 \%$ of the natural uranium which is found in the whole Earth's crust in form of uranium ores and in trace amounts in all kinds of rocks and soils $[2,3]$ whereas the thorium is found in several rocks and soils in a concentration which varies from $8,1 \mu \mathrm{g} \cdot \mathrm{g}^{-1}$ to $33 \mu \mathrm{g} \cdot \mathrm{g}^{-1}$ [3]. Geographical and geological factors may cause differences among those natural radionuclides concentrations in environmental samples [2]. Uranium concentrations in the soil vary from $1 \mu \mathrm{g} \cdot \mathrm{g}^{-1}$ to $5 \mu \mathrm{g} / \mathrm{g} \mu \mathrm{g} \cdot \mathrm{g}^{-1}$ [4] and, to be considered a placer, the uranium field concentration must be 400 to 2,500 times greater than that average concentration [5].

The main emitters of alpha that can be present in potable water are the ${ }^{238} \mathrm{U},{ }^{234} \mathrm{U},{ }^{232} \mathrm{Th},{ }^{226} \mathrm{Ra}$ and ${ }^{210} \mathrm{Po}$ and beta ${ }^{40} \mathrm{~K},{ }^{228} \mathrm{Ra} \mathrm{e}{ }^{210} \mathrm{~Pb}$, in different concentrations [6]. The identification and concentration of each radionuclide present in the water requires expensive time-consuming analyses that are many times unnecessary. In general, gross alpha and beta analysis, one of the simplest radioanalytical procedures, is used as the first step as a screening method, for being a very fast, safe and low cost method [7]. In the WHO (World Health Organization) guidelines for drinking water quality the recommended levels are 
0, $5 \mathrm{~Bq} \cdot \mathrm{L}^{-1}$ for gross alfa and $1 \mathrm{~Bq} . \mathrm{L}^{-1}$. If the measured values are above the reference levels, nuclide specific analysis is required [7].

In this work the levels of alpha and beta radioactivity of the waters used by the population resident in the proximities of of a high natural radioactivity region of central south Bahia state, Brazil were determined, as the region of interest is rich in uranium ore and the hydric resources sometimes are used without a previous radiation screening.

\subsection{Study area}

Brazil is the owner of the seventh greatest geological reserve of uranium in the world, with approximately 310 thousand tons. This reserve is distributed among greater placers, for instance Itatiaia, Ceara (142,500 tons), where the mineral is associated with phosphate and ornamental rocks which are economically exploitable; and Lagoa Real, in Bahia (100,770 tons) and other smaller placers like Gandarela, Minas Gerais, where there is gold associated with the uranium, Rio Cristalino, in Pará; and Figueira, Paraná $[8,9]$. The Lagoa Real Uranium Province, in the region of Caetite and Lagoa Real, situated in South Central Bahia, is considered the most important monomineralic province of Brazil, discovered in the 1970's from an aerogammametric survey.

The uranium province of Lagoa Real comprehends a very large area of approximately $1200 \mathrm{~km}^{2}$, with 34 uranium deposits, and the metamorphic foundation present in the region, named gneissic complex of Lagoa Real, presents structural features where albitites, the carrier rocks of uranium, are found [10]. The study area comprehends the towns of Caetite, Lagoa Real and a small part of the Livramento de Nossa Senhora town, with 102,544 inhabitants [11]. Climate is tropical becoming subdivided in semi-arid and sub humid to dry depending on the town with temperatures ranging from $14.5^{\circ} \mathrm{C}$ to $33^{\circ} \mathrm{C}$ [12]. Annual rainfall is roughly $800 \mathrm{~mm}$ with two well defined seasons: the humid season, from October to April, with $80 \%$ of rain occurrence, and the dry season, from May to September [13].

The urban population that lives in the proximities of the uranium province in the towns of Caetite, Lagoa Real and Livramento uses water from public supply which is treated and distributed. In the rural area water treatment for people's usage is almost inexistent, and due to long dry periods and the intermittence of the rivers in the region, the population obtains water from wells, cisterns, using small weirs, reservoirs and dams which are supplied during the rain [13].

\section{MATERIALS AND METHODS}

In the present work, a total of 32 points of superficial, underground and public supply waters in the towns of Caetite, Lagoa Real and Livramento de Nossa Senhora were assessed. Table 1 shows the sampling points characterized by their geographical location and the font of water supply. The rainwaters were collected directly from clay filters, as some locals used to drink that water, instead of well water.

The water samples were collected and stored in $2 \mathrm{~L}$ polyethlyene recipients and acidified, maintaining the $\mathrm{pH}<2$. In the laboratory, initially,a volume of $1 \mathrm{~L}$ was concentrated on a hotplate until $50 \mathrm{~mL}$. After, an aliquot of $4 \mathrm{~mL}$ was pipetted on a $60 \mathrm{~mm}$ diameter stainless steel planchet, drying to evaporation under an infrared light. All samples were prepared in triplicate. The samples were measured with a Berthold LB 770-5 10-chambers low background gas flow proportional detector. Each sample was measured for three cycles of 400 minutes.

The efficiency calibrated system was carried out by using standard solutions from the PNI-IRD program [14]. The average efficiency was $22 \%$ for alpha and $42 \%$ for beta.

\section{RESULTS}

The samples were collected in two runs, the first one, in January 2010, corresponding to the rain season, and the second one in July 2010, corresponding to the dry season. 
Table 1. Sampling points of water from several locations in central south Bahia state, Brazil, for gross alpha and beta analysis.

\begin{tabular}{|c|c|c|c|}
\hline Municipality & Sampling Point & Location & Font of water supply \\
\hline \multirow[t]{20}{*}{ Caetité, BA } & 1 & Urban Zone & public supply \\
\hline & 2 & Urban Zone & public supply \\
\hline & 3 & Urban Zone & public supply \\
\hline & 4 & Urban Zone & public supply \\
\hline & 5 & Urban Zone & public supply \\
\hline & 6 & Urban Zone & well \\
\hline & 7 & Rural Zone (Fazenda Barreiro - Maniaçu) & well \\
\hline & 8 & Rural Zone (Fazenda Barreiro - Maniaçu) & water tank \\
\hline & 9 & Rural Zone (Fazenda Carambola - Maniaçu) & well \\
\hline & 10 & Rural Zone (Fazenda Cercadinho-Maniaçu) & well \\
\hline & 11 & Rural Zone (Fazenda Cercadinho-Maniaçu) & rainwater \\
\hline & 12 & Rural Zone (Fazenda Gameleira-Maniaçu) & Dam \\
\hline & 13 & Rural Zone (Fazenda Gameleira-Maniaçu) & Dam \\
\hline & 14 & Rural Zone (Fazenda Gameleira-Maniaçu) & rainwater \\
\hline & 15 & Rural Zone & well \\
\hline & 16 & Rural Zone & well \\
\hline & 17 & Rural Zone (Juazeiro) & well \\
\hline & 18 & Rural Zone (Juazeiro) & well \\
\hline & 19 & Rural Zone (Juazeiro) & well (filtered water) \\
\hline & 20 & Rural Zone (Riacho da vaca) & well \\
\hline \multirow[t]{10}{*}{ Lagoa Real, BA } & 21 & Rural Zone (Localidade Peixe) & well \\
\hline & 22 & Rural Zone & well \\
\hline & 23 & Rural Zone (Sao Pedro) & Dam \\
\hline & 24 & Rural Zone (Lagoa Grande) & pond \\
\hline & 25 & Rural Zone (Lagoa Grande) & well \\
\hline & 26 & Rural Zone (Lagoa Grande) & well (filtered water) \\
\hline & 27 & Rural Zone (Vila Taperinha de Lagoa Grande) & well \\
\hline & 28 & Urban Zone & water before filtration \\
\hline & 29 & Urban Zone & well \\
\hline & 30 & Urban Zone & public supply \\
\hline $\begin{array}{l}\text { Livramento de } \\
\text { Nossa Senhora }\end{array}$ & 31 & Rural Zone (São Timóteo) & well \\
\hline BA & 32 & Rural Zone (São Timóteo) & Housing \\
\hline
\end{tabular}

In the rain season, the total alpha activities concentrations varied from $0,020 \pm 0,001 \mathrm{~Bq} \cdot \mathrm{L}^{-1}$ to $0,45 \pm 0,027 \mathrm{~Bq} \cdot \mathrm{L}^{-1}$ and the total beta activities concentrations varied from $0,040 \pm 0,003 \mathrm{~Bq} \cdot \mathrm{L}^{-1}$ to $1,39 \pm 0,081 \mathrm{~Bq} \cdot \mathrm{L}^{-1}$.

In the dry season, the total alpha activities concentrations varied from $0,010 \pm 0,001 \mathrm{~Bq} \cdot \mathrm{L}^{-1}$ to $0,57 \pm 0,033 \mathrm{~Bq} \cdot \mathrm{L}^{-1}$ and the total beta activities concentrations varied from $0,010 \pm 0,006 \mathrm{~Bq} \cdot \mathrm{L}^{-1}$ to $1,63 \pm 0,14 \mathrm{~Bq} . \mathrm{L}^{-1}$.

All gross alpha and beta concentrations activities results are presented together in Fig. 1.

\section{CONCLUSIONS}

The overall results from Fig. 1 show that, for the Caetite and Livramento de Nossa Senhora regions there is no significant difference between the rain and dry seasons. Also, for these two regions, all values are within the WHO recommended limits for both alpha and beta activities. 


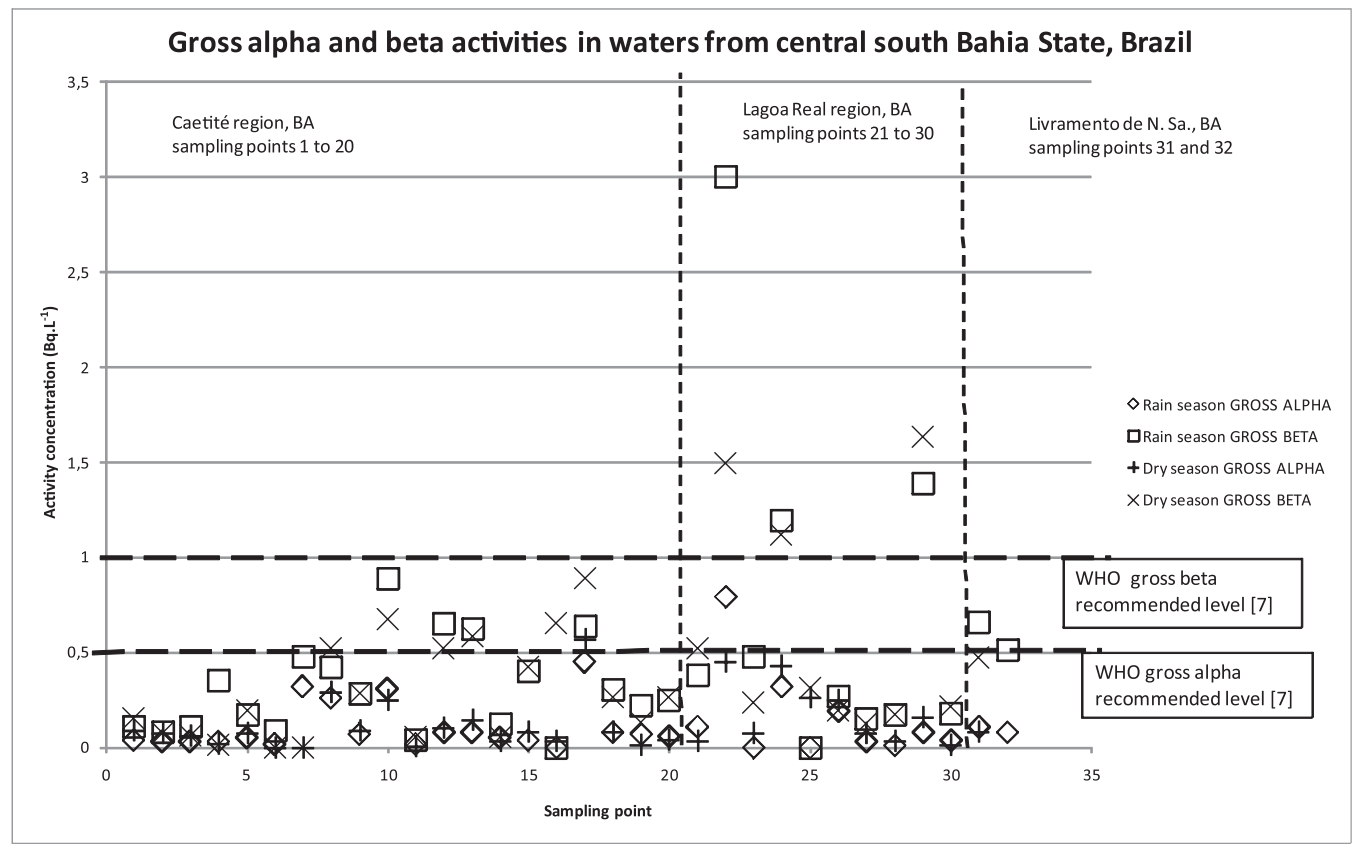

Figure 1. Gross alpha and beta activities in surface, underground and drinking waters of Caetité, Lagoa Real e Livramento de Nossa Senhora, central south Bahia state, Brazil, separated by regions (Dashed horizontal lines represents the gross alpha and beta WHO recommended levels [7]).

The Lagoa Real region presents the highest activities concentrations, particularly for the gross beta activities of the sampling points 22,24 and 28 .

For a complete assessment, further uranium concentrations determinations for the same samples will be performed.

\section{Acknowledgments}

The authors would like to thank Sandra Damatto and Marcelo B. Nisti for the invaluable aid with the experimental work and data processing and the Union of Farmers of Caetite represented by the President Genilton Xavier, for having provided the transportation for field research and a guide who helped us with the difficult task of locating the points of collection of water samples to be analyzed.

\section{References}

[1] UNSCEAR - United Scientific Committee on the Effects of Atomic Radiation, The 2000 Report to the General Assembly with scientific Annexes. New York: United Nations, 2000.

[2] M. Bolca, M.M. Saç, B. Çokuysal, T. Karal , E. Ekdal. Radioactivity in soils and various foodstuffs from the Gediz River Basin of Turkey, Radiation Measurements, volume 42, issue 2, February 2007, Pages 263-270.

[3] EISENBUD, M. Environmental Radioactivity. 2nd ed. Academic Press, Orlando, 1987.

[4] D. M. Bonoto, Radioatividade nas águas : da Inglaterra ao Guarani, São Paulo: Editora UNESP, 2004.

[5] W. Teixeira, M. Toledo C. M., T. R. Fairchild, F. Taioli. Decifrando a Terra. São Paulo: Oficina de Textos., 2000. 
[6] V. Jobbágy, U. Watjen, J. Meresova. Current status of gross alpha/beta activity analysis in water samples: a short overview of methods, J. Radioanal Nucl Chem, 2010, 286:393-399.

[7] WHO - Word Health Organization. Guidelines for Drinking-water Quality Third edition incorporating the first and second addenda, Volume 1 Recommendations, 2008.

[8] AMBIENTE BRASIL Energia/Nuclear. http://ambientes.ambientebrasil.com.br/energia/nuclear, acesso em 07/03/2011.

[9] INB- Indústrias Nucleares do Brasil. http://www.inb.gov.br/inb/ acesso 07/03/2011.

[10] S. N. P. Guimarães, V. M. Hamza. Avanços na caracterização das estruturas Geológicas em subsuperfície da província uranífera Lagoa Real (BA) a partir de dados Aerogeofísicos, UNESP, Geociência, v. 28, n.3. p. 273-286, 2009.

[11] IBGE - Instituto Brasileiro de Geografia e Estatística, http://www.ibge.gov.br/censo2010/, acesso em 06/03/2011.

[12] SEI, 2011. Informações Geoambientais da Superintendência de Estudos Econômicos e Sociais da Bahia. Disponível em: <http://www.sei.ba.gov.br/geoambientais/ . Acesso em: 06/03/2011.

[13] INB - Industrias Nucleares do Brasil. EIA/RIMA Complexo Uranífero Minero Industrial de Lagoa Real. Caracterização de Empreendimento Tomo III- Anexos, Parte IIIa, 1997. 